\title{
Varieties of capitalism, neoliberalism and the economic crisis of 2008-?
}

\author{
Jason Heyes, Paul Lewis and Ian Clark
}

\begin{abstract}
This article examines the responses of national governments to the economic crisis that commenced in 2008. We argue that the current search for new bases for accumulation is leading to reforms designed to weaken the position of labour. Moreover, the tendency towards a weakening of labour's position was already evident across different 'varieties of capitalism' before the crisis erupted. We discuss the implications for comparative institutional analysis and stress the need for a renewed focus on the underlying dynamics of capitalist economies.
\end{abstract}

\section{INTRODUCTION}

During a visit to the London School of Economics in 2009, Queen Elizabeth II asked why economists had failed to foresee the economic crisis that erupted in 2008. In fact, a number of economists had predicted a financial crisis (e.g. Brenner, 2004; Harvey, 2005), but these individuals were typically far from the centres of power and working outside the mainstream of the economics profession. The assumption of most economists was that economic stability could be ensured in perpetuity thanks to improvements in monetary policy that had tamed the business cycle and produced a 'great moderation'. ${ }^{1}$ Analyses that assumed the stability of capitalist economies were not confined to the mainstream, however. The Varieties of Capitalism (VoC) analysis associated with Hall and Soskice (2001), and which has proved highly influential in the field of industrial relations, was also blind to the sources of instability developing within capitalist economies. As this article demonstrates, a preoccupation with institutions, and an associated neglect of social agency and the dynamics of the capitalist mode of production, has left the $\mathrm{VoC}$ frame of analysis ill-equipped to provide insights into the causes and consequences of the current crisis. In particular, the VoC literature has little analytical purchase on the growth of the finance sector as a distinctive fraction of capital, the role of the state in promoting specific accumulation

$\square$ Jason Heyes is Reader in Human Resource Management, Birmingham Business School, University of Birmingham, Paul Lewis is Lecturer in Political Economy, Birmingham Business School, University of Birmingham and Ian Clark is Reader in HRM and Industrial Relations, Birmingham Business School, University of Birmingham. Correspondence should be addressed to Jason Heyes, Birmingham Business School, University of Birmingham, University House, Edgbaston Park Road, Birmingham B15 2TY; email: j.heyes@bham.ac.uk

${ }^{1}$ For critiques of the assumptions that have guided macroeconomic theory and policy recommendations over the past 30 years, see Mason (2009) and Quiggin (2010). 
paths and shifts in capital-labour relations, all of which have influenced the causes and specific characteristics of the crisis. The VoC framework also provides an inadequate guide for understanding responses of national governments to the crisis and the implications for workers.

We spell out our arguments theoretically and empirically in the four parts of the article. The first section examines competing explanations of the causes of the crisis and develops the theoretical category of financialisation. Part two examines responses to the crisis. We argue that the current search for a new basis for accumulation is resulting in the articulation and implementation of reforms designed to weaken the position of labour and that this tendency is observable in countries associated with different 'varieties of capitalism'. While the extent of attacks on welfare and employment rights and the specific content of policies differ in important respects, it is nevertheless clear that protections are being eroded in both 'coordinated market' and 'liberal market' economies as governments drive through reforms to deliver austerity. In the third section, we demonstrate that the tendency towards a weakening of labour's position was already evident in both 'varieties of capitalism' long before the crisis erupted. This tendency cannot be easily explained via the $\mathrm{VoC}$ framework of analysis, which by contrast predicts that governments, employers and trade unions in coordinated economies have an incentive to preserve employment and social protections because of the competitive advantages they supposedly confer. In the conclusion, we argue that comparative political economy and industrial relations should move beyond a preoccupation with static institutions and engage with the dynamics of capitalism, class relations and the capitalist state.

\section{THE DISPUTED ORIGINS OF THE CRISIS}

The current crisis started in the United States in summer 2007 with the failure of two Bear Stearns hedge funds that had previously speculated in unsafe mortgage-backed securities (MBS). In September 2008, the US Treasury Secretary brought before Congress an emergency plan to bail out the financial sector by purchasing MBS. The plan was passed but set off a global chain reaction of panic leading to plummeting share values and the prospect of widespread bank failures. However, while the immediate trigger for the ensuing contraction in global liquidity can be relatively easily comprehended, the underlying causes continue to be matters of debate. One popular interpretation focuses on the growth in the importance of the financial sector since the early 1980s, a process that governments have encouraged in various ways, particularly through the relaxation of controls on the international mobility of financial capital. According to this argument, inadequate regulation of financial services and the consequent development of a 'bonus culture' created incentives for extreme risk-taking behaviour, leading to speculative investments in unsafe assets (Elliott and Atkinson, 2009). Other interpretations have focused on the relationship between finance and the real economy. According to Foster and Magdoff (2009), for example, the expansion of the finance sector and the roots of the crisis lie in a long-standing decline in opportunities for firms to make productive investments and a consequent need to find alternative means of absorbing surplus value. ${ }^{2}$ By contrast, Nolan (2011) had empha-

\footnotetext{
${ }^{2}$ Their arguments in this regard extend Baran and Sweezy's (1966) earlier analysis of capitalists' efforts to overcome supposed tendencies to stagnation generated by the growth of 'monopoly capitalism'.
} 
sised the importance of accumulating weaknesses in production, evidenced by deteriorating productivity growth in the decade that preceded the eruption of the crisis.

The position taken in this article is that the crisis is best understood as the culmination of processes stemming from measures that were intended to resolve the crisis of the 1970s and that were extended over the subsequent quarter-century. These measures, commonly referred to collectively as 'neoliberalism', took the form of state policies designed to weaken the position of labour and deliver a decisive shift in the balance of social forces in favour of the capitalist class. The term neoliberalism has been employed in a variety of ways and has been subject to competing interpretations (Harvey, 2005; Heyes and Nolan, 2010). Our own interpretation is in line with that of Harvey (2010: 10), who regarded neoliberalism as a 'class project that coalesced in the crisis of the 1970s' and that 'legitimised draconian policies designed to restore and consolidate capitalist class power'. Harvey argued that a key characteristic of neoliberalism was the use of state power to protect financial interests. Gamble (2009: 78) similarly argued that 'neo-liberalism gives priority to capital as money and therefore to the financial circuit of capital rather than to the production circuit'. Understanding neoliberalism, and by extension, the post-2007 crisis, therefore necessitates that attention be paid to the relationship between capital, labour and the state, on the one hand, and to particular fractions of capital, on the other.

The term financialisation is often used as a way of expressing the growth in the scope and importance of the role of finance in capitalist economies. Financialisation is, however, a contested concept. Callinicos (2010) identified three possible meanings. The first connotes a fusion of banking and industrial capital. Supporting evidence for this idea, first developed by Rudolf Hilferding in the early 20th century, is weak, however: industry's reliance on bank loans as a source of finance varies considerably between countries, being particularly strong in Germany and Japan but far weaker in the United States, where firms often self-finance investments via retained profits. However, examples of fusion may be seen in reverse, to the extent that non-financial companies make a large proportion of their profits from in-house financing arms, for example, General Electric (GE) and auto manufacturers (see Froud et al., 2006). The second interpretation of financialisation that Callinicos identified captures the belief that the finance sector has become increasingly autonomous, while the third emphasises the extent to which the web of finance has extended to encompass a wider range of actors, involving them ever more deeply in financial markets (e.g. through increased mortgage lending, provision of credit). The latter could not have occurred without the introduction of new financial products, such as MBS, collaterised debt obligations and credit default swaps. This alphabet soup of products gave the impression that risk had been reduced through its more efficient allocation, allowing banks and shadow banks, such as hedge funds, to tap into a deeper pool of investors than ever before. Such a large-scale expansion of credit also required the recycling of global trade imbalances from surplus to deficit countries through such innovations (Lewis, 2010; Turner, 2009).

Complementary to these interpretations are the dynamics of profit financialisation, recognising the growth in the profit share of the financial sector of the economy and the importance of financial transactions to the profitability of non-financial firms, and control financialisation, whereby the maximisation of shareholder value has become the driving force of corporate governance for listed companies (Deeg, 2010; Nölke and Perry, 2007). A central operating presumption of financial capitalism is that active owner-investor engagement in the interests of investors and shareholders not only creates the market for corporate control but, in addition, promotes efficiency by 
incentivising managers to explicitly act in the interests of investor-owners rather than an established if disparate group of stakeholders inside the firm (Jensen and Murphy, 2009). These dimensions of financialisation are, in our view, not discrete or mutually exclusive but capture integrated processes that are both demonstrable and important. Despite the lack of widespread evidence for 'fusion', the distinction between finance and industrial capital also remains analytically important. Beginning in the early 1980s, the UK and US governments chose to pursue policies that privileged the interests of finance above those of industry in the belief that finance could form the basis of a new growth model. The US and UK economies subsequently experienced a substantial expansion of the finance sector. The contribution of financial services to US gross domestic product (GDP) increased from around 2 per cent in 1950 to approximately 8 per cent in 2007. The finance sector's contribution to the economy also increased rapidly in the UK: financial services accounted for 5 per cent of gross value added (GVA) in 1970, increasing to 8 per cent by $2007^{3}$ (Feinstein, 1972; Mitchell, 1988; Philippon, 2008; Office of National Statistics (ONS) and Bank of England calculations; cited in Haldane et al., 2010). The finance sector's share of total corporate profits also mushroomed across the advanced economies. In the UK, which witnessed the largest increase, the finance sector's share increased 10-fold, from an average of 1.5 per cent of total corporate profits between 1948 and 1978 to 15 per cent in 2008 (Haldane et al., 2010).

The elements and degree of financialisation have differed between countries, reflecting differences in the development and organisation of finance, the extent to which financial institutions have developed a transnational orientation, and the importance of the financial sector to capital accumulation within particular countries (Macartney, 2011). ${ }^{4}$ In highlighting the importance of global imbalances, the financial crisis suggests two distinct strategies of accumulation with a symbiotic and ultimately crisis producing interdependence. The first, which we may label export-led growth, was characterised by countries running large current account surpluses and corresponding capital account deficits, recycling those surpluses into trading partners. This strategy, as exemplified by East Asian countries including Japan and China and Germany, relies on competitiveness in international markets, primarily in goods, but increasingly in tradable services. The second strategy of accumulation we may label financeled growth. Essentially, this reflects an increasing dependence of nation states upon finance capital. Direct dependence derives from the size and profitability of financial services as a sector, the number of jobs that it supports, its balance of trade and the tax revenue that it generates. Just as important is a country's indirect dependence upon finance deriving from the provision of cheap, unsecured credit to consumers and businesses. This serves to create demand in the economy and provides a second important mechanism for accumulation through inflating asset prices, particularly

\footnotetext{
${ }^{3}$ The difference between gross domestic product (GDP) and GVA calculated for the whole economy is that the former is at market prices - including product taxes and subtracting subsidies - and the latter is at basic prices-excluding product taxes (ESA, 1995).

${ }^{4}$ Engelen and Konings have shown that developed economies differ on measures of the depth of financial markets - stock and bond markets as a proportion of GDP, on financial openness - inward and outward Foreign Direct Investment (FDI), foreign ownership of public exchange traded equities and the percentage of pension fund assets allocated to foreign markets, and on financial innovation - securitisation outstanding as a percentage of GDP (2010: 609-615). Such differences are related to national specificities including the extent to which pension funds are funded rather than pay-as-you go, the extent to which housing is privately owned and treated as a store of wealth (Schwartz and Seabrooke, 2009) and the extent to which economies are open and internationalised.
} 
residential property and stock markets. The boom in asset prices enables further credit to be extended, increasing demand yet further and providing an impression of effortless wealth accumulation. Countries that followed this strategy included the United States, the UK, Spain and Ireland. As a consequence, ratios of household debt to gross disposable income in these countries grew to become the highest among all developed countries (IMF (International Monetary Fund), 2008: 18).

In both strategies of accumulation, we can identify logics that entail a weakening of the position of labour in relation to capital. The mechanism for finance-led accumulation has been well rehearsed through the demands that control financialisation creates for high returns on capital and the consequences of this for stable, well-paid employment (Froud et al., 2006; O’Sullivan, 2000: 192-193). Flexible labour markets, minimal welfare states and individualised wages are entirely consistent with the optimising logic of unfettered financial capital seeking out its most profitable activities (Lewis, 2009: 54-56). Export-led accumulation creates demands for unit cost reduction, which fall on labour directly through calls for more flexible labour markets and indirectly through reductions in non-wage costs such as the taxes that fund welfare state services. In the case of Germany, changes in the financing of German companies have resulted in additional pressure to generate higher returns on capital, which, in turn, has created downward pressure on wages (Streeck, 2009). Even prior to the crisis, these pressures had begun to have an impact upon the labour share in Germany, precipitating a large rise in earnings inequality, and begun to undermine sectoral wage bargaining.

As Nolan (2011: 15) had recently argued, the weakening of the position of workers and their unions and the 'diminishing capacity of labour institutions to exert any influence over the definition of public policy (nationally and internationally) towards industry, work and regulation during the last quarter of a century' played a key part in the creation of crisis conditions. The shift in the balance of social forces against labour has been widespread and has taken a number of forms. Wage repression is of particular analytical importance in understanding the conditions that gave rise to the crisis. Since the 1980s, there has been a widespread tendency for labour's share of total income to diminish as productivity increases have outstripped growth in real wages. In many countries, real wages have virtually stagnated. In the United States, the median wage fell until the mid-1990s, followed by average growth of less than half a per cent per annum (Glyn, 2006: 116). In Europe and Japan, average real wages have increased at a rate of around 1 per cent per annum (ibid.). According to an analysis by the International Institute for Labour Studies (IILS) (ILO, 2008), the pattern of decline has been similar across countries, with particularly rapid falls in the share of wages occurring in the early 1980s and early 2000s. The exceptions to the trend have been the Central and Eastern European (CEE) economies, the Russian Federation and the countries of the Middle East and North Africa, where the wage share remained roughly constant (ILO, 2008: 6). Within-country inequalities, as measured by changes in the Gini coefficient, also increased in two-third of the 85 countries covered by the IILS study. Inequality has increased despite the claims of advocates of financial market liberalisation that benefits would 'trickle down' to all members of society. Since 1990, particularly large increases in inequality have been witnessed in former Eastern bloc countries (Hungary, Poland) and the United States. However, an increasing wage gap between high and low earners is evident even in countries such as Sweden and Denmark (ILO, 2008: 12). In many European economies, increased inequality was evident in a growth in the differential between top and middle earners, with little change in the differential between the middle and bottom. In the United 


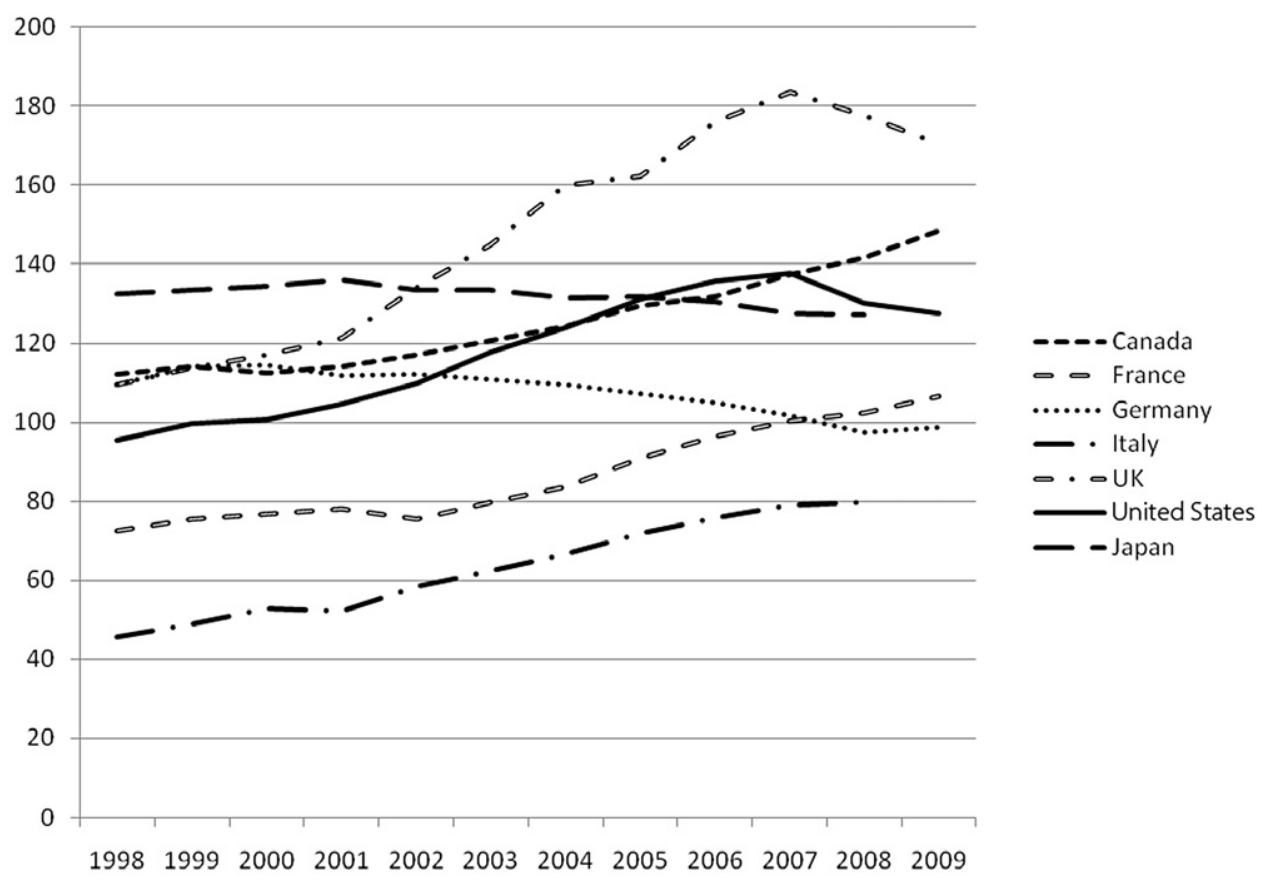

Figure 1: Household indebtedness, 1998-2009

Note: The data show liabilities, expressed as a percentage of nominal disposable income. Source: OECD statistics.

States and in the UK, by contrast, the differential between middle and bottom also expanded. According to Weeks (2005: 11), 'increases in inequality have been the result of policies, most importantly, policies that have weakened the power of organised labour'. His scrutiny of empirical evidence for seven OECD countries also led him to conclude that 'reductions in government social expenditure and abandoning full employment as a policy goal have also played a substantial role' in the increase in inequality.

Financialisation has both been facilitated by the weakening of labour's position and contributed to the weakening by exposing workers to risk in the form of debt. As wage shares have fallen and inequality increased, personal indebtedness has increased substantially as a mechanism to maintain consumption in many developed countries. While the trend is most developed in the highly financialised Anglophone countries, interrupted by the crisis in the United States and the UK, there is also clear evidence of growing household indebtedness in France and Italy from a lower base. Only Germany and Japan, as exemplars of export-led accumulation, are exceptions (see Figure 1). Financial liberalisation has also eroded the bargaining power of workers. A recent analysis by the ILO (2009: 53) concluded that 'for the five most financialised countries, wage share declined by 3.6 per cent over the period 1989 to 2005, while for the five least financialised countries, wage share declined by 2 per cent'. The effectiveness of industrial relations institutions, such as extensive collective bargaining coverage and coordinated bargaining, which had previously had the effect of reducing inequality by compressing earning differentials has, according to the ILO, been 
reduced as a consequence of financial liberalisation (ILO, 2009: 107-109). An increased emphasis on the maximisation of shareholder value and associated shorttermism points to a connection between shareholder value and downsizing as firm level drivers and neoliberalism as a business system driver (Folkman et al., 2009; Lazonick and O'Sullivan, 2000). The tendency towards control financialisation has been exacerbated by the increased involvement of private equity funds in the ownership and management of 'portfolio' firms. Private equity investors aggressively assert the interests of investors and shareholders over those of other established stakeholders but as owners, not managers (Clark, 2009). As intermediary owners, private equity investors assert their interests by redefining relationships with stakeholders and transforming portfolio firms into financialised assets, whereby short-term financial gains for investors are secured by extracting value from employees or supplier stakeholders (Clark, 2011; Rodrigues and Child, 2010: 1324-1325). Financialisation is likely to be experienced by employees as draconian restructuring.

\section{RESPONDING TO THE CRISIS}

The tendency towards a weakening in the position of labour, already well under way prior to the eruption of the crisis, is being further entrenched in the aftermath of the economic shock as a consequence of attempts by states to resuscitate national economies. This section of the article demonstrates this claim by comparing crisis responses in Ireland, the UK, Germany and the Czech Republic. In the terms developed by Hall and Soskice, Germany is a prime example of a 'coordinated market economy' (CME), in which institutions and networks help coordinate economic activity by providing access to information, skills and other resources. Ireland and the UK were classified by Hall and Soskice as 'liberal market economies' (LMEs) in which coordination is achieved through formal contracting and market-mediated exchanges. Nevertheless, Ireland has differed from the UK in key respects, notably the extent to which the Irish government, trade unions and employer organisations have participated in tripartite social dialogue. The latter has also been an important element in economic and social policy development in the Czech Republic. While Hall and Soskice's original typology did not encompass CEE economies, a recent attempt to extend it has characterised the Czech Republic as a 'liberal-dependent' economy (LDE) that resembles the LME type while typically having a greater reliance on foreign capital (King, 2007).

In discussing crisis responses, it is useful to distinguish between two phases. In the first phase, the principal concerns of national governments were to shore up the banks, prevent a collapse of consumer confidence and demand and address the rapidly escalating threat to jobs. The 'jobs crisis' has had a number of dimensions, the most prominent of which has been an escalation in unemployment. Every OECD country, with the exceptions of Poland and Germany, experienced an increase in the rate of unemployment over the period 2007-2009. Prior to the beginning of the crisis, the unemployment rate across all OECD countries stood at a 27-year low of 5.6 per cent. By October 2009, it had reached 8.8 per cent. The percentage increase in unemployment in a number of individual OECD countries has been considerably greater than the average. In Ireland, the rate of unemployment increased from 4.6 per cent in 2007 to 13 per cent by the fourth quarter of 2009. Over the same period, unemployment in Spain increased by more than 10 percentage points to reach 19 per cent (European Commission, 2010). 
The most important feature of 'phase one' was the injection of massive fiscal stimuli involving tax cuts and/or increased government spending. Interest rates were cut, banks were provided with injections of capital and, in some cases, nationalised as government sought to stave of financial collapse. The cost of banking bailout has been estimated to have cost the equivalent of one-sixth of world GDP (Torres, 2010: 231). During this period, the crisis was commonly framed in terms of irresponsible bankers and inadequate or absent regulatory frameworks and agencies. Media and politicians of all political stripes proclaimed the death of neoliberalism and argued that dominant economic concepts of 'rational expectations' and 'efficient markets' should be consigned to the dustbin of history. President Sarkozy's claim that 'Laissez faire is finished' (Callinicos, 2010: 5) neatly captured what appeared to be the consensus view.

Across the EU, labour market measures accounted for a relatively small proportion of stimulus spending compared with tax cuts and transfers. Khatiwada's (2009: 18-19) analysis, which focused on 10 advanced and 12 developing economies, suggested that on average, 1.79 per cent of total fiscal package expenditure was spent on employment measures, although a substantial proportion of infrastructure expenditure was also directed at job creation measures. A number of countries extended the coverage of unemployment benefits (Japan, Brazil, Chile and the United States) or increased the generosity of unemployment benefits for temporarily laid off workers (France, Italy, Switzerland) (Khatiwada, 2009: 21). Training programmes for unemployed workers were also widespread, and many countries increased the intensity of job search assistance by offering earlier personalised assistance or career counselling (Australia, Czech Republic, Denmark, Finland, Ireland and the UK). However, there were also notable differences in responses, particularly in relation to support for measures designed to preserve jobs. The most notable aspect of Germany's approach to tackling the employment dimension of the economic crisis was the extensive use of working time reductions as a means of reducing labour costs and preventing job losses. The number of German workers in short-time work measures increased from an average 20,000 per month in 2007 to a peak of 1.5 million during 2009 (Heyes, forthcoming). Financial incentives were also provided so as to encourage employers to provide additional training opportunities for partially unemployed workers.

Following discussions by the tripartite Council for Economic and Social Agreement (Rada hospodářské a sociální dohody ČR (RHSD)), the Czech government also introduced a number of short-time working and training programmes. In comparison, government support for measures to preserve jobs in the UK and Ireland was far more limited. While workers and employers in a number of firms in the UK reached agreements relating to reductions in working time, the government did not introduce support for short-time work measures, to which the Confederation of British Industry (CBI) was opposed. Limited support was provided in Ireland, although the short-time working arrangements were relatively inflexible and only a small number of workers were involved (no more than 4,000 by the end of 2010) (Heyes, forthcoming).

If fiscal stimulus was the defining characteristic of phase one of the response to the crisis, the defining characteristic of phase two has been fiscal austerity. In an effort to justify massive cuts in government spending, governments have sought to re-frame the crisis as a product of intervention and regulation (i.e. too much state intervention in the economy) (Thompson, 2009). Supranational institutions (in particular, the IMF), credit rating agencies and financial interests are encouraging a return to pre-crisis orthodoxy and the re-establishment of 'sound finance' through debt reduction. As Glyn (2006: 35-37) had shown, financial interests tend to support debt reduction via 
cuts to government spending rather than increased taxation, and the current crisis has proved no exception. Austerity measures have further weakened the position of workers in a number of ways. Cuts in state expenditure have resulted in wage freezes or cuts and job losses in the public sectors of several European economies. These developments have led to strikes, protests and in the case of Ireland, the breakdown of the tripartite social dialogue that has been a key feature of Irish industrial relations since 1987.

The crisis has also had implications for employment rights and social protections. Governments and employers have argued that any moves to strengthen employment rights would impose additional costs and administrative burdens on business that would in turn impede economic recovery and job creation. In Ireland, plans to introduce increased penalties for abuses of employment rights have been indefinitely delayed. In return for an $€ 85$ billion emergency rescue package provided by the IMF and the European Central Bank in late 2010, the Irish government agreed to increases the state pension age, cut public sector pay and pensions and reduce the national minimum wage by 12 per cent. Following the general election of 2011, the minimum wage was restored to its former level, although ministers now have freedom to make changes to the minimum wage irrespective of the views of trade unions and employers. In Germany, proposals for a national minimum wage have been shelved, opposition within government to sectoral minimum wages has increased and a bonus scheme for employers who take on apprentices has been abandoned. UK employers successfully lobbied for a delay to the implementation of the EU Agency Workers Directive, the continued exemption of small businesses from recently introduced legislation conferring on workers an entitlement to request time off work for training and the abandonment of plans to increase the number of civic duties for which workers may take time off work. The government has diluted protections relating to unfair dismissal and has sought to discourage workers from taking cases to Employment Tribunals. Furthermore, at the time of writing, the CBI is lobbying the government to increase restrictions on the ability of workers to take strike action, a proposal to which government ministers appear to be sympathetic. The Czech coalition government has echoed the UK government in claiming that employment protections act as a brake on job creation. In 2010, it announced proposals for changes to the Labour Code that would increase employers' freedom to employ workers on temporary contracts, extend the 'probationary period' during which workers could be dismissed without reason and reduce redundancy payments for workers with less than three years of service. The government's proposals resulted in industrial action and public protest and while reforms were eventually introduced in 2011, they were less extensive than originally envisaged.

A number of employment policy reforms have been aimed at forcing unemployed workers to accept offers of work or training. These reforms represent an extension and intensification of workfare measures that have taken root in much of Europe over the past decade (Heyes, 2011). The level and duration of unemployment benefits in Ireland was cut in 2009 and 2010, and the number of contributions that workers must pay before becoming eligible for unemployment benefit has been doubled. In Germany, parental leave benefits have been reduced, transitional supplements for unemployed workers transferring to 'long-term unemployment' benefit have been removed and the government has ceased paying the pension contributions of people receiving basic income support. Employment policy reforms have also occurred in Britain. The government has announced that under its new 'Work' programme, job 
advisors will be empowered to withhold benefits from unemployed workers who fail to accept a 'reasonable' job offer and will no longer be able to use their discretion to allow unemployed workers to remain on benefits. In addition, the government has begun to test the work fitness of people claiming incapacity benefit, with the aim of transferring many of these people to Job Seeker's Allowance or a new Employment Support Allowance and linking their benefit entitlements to their willingness to seek paid employment. Similar steps have been taken in the Czech Republic. The centreright coalition government, which came to power in May 2010, has cut unemployment benefit entitlements for workers who quit their job or receive a severance payment and has linked benefit entitlements more closely to workers' willingness to engage in active job search or training.

\section{VoC IN CRISIS?}

In addition to the LME, CME and CEE/LDE examples already described, 'Mediterranean market economies' (MMEs) such as Portugal and Spain have made, or sought to make, substantial cuts in public expenditure, involving public sector wage cuts and reductions in the value of social benefits, and have also sought to weaken employment protections. In other words, while responses may vary across the EU in terms of their specific content, pace and degree, common tendencies have emerged across different 'varieties of capitalism'. This development is not easily explained by the VoC approach, which emphasises that responses to 'exogenous shocks' will differ between the varieties of capitalism (Iversen, 2007). Responses certainly have differed in important respects, notably the more extensive use of short time working measures in CMEs compared to elsewhere, yet there have also been similarities and these have become more apparent as policy makers have turned their attention to the problem of re-starting economic growth.

The inability of the VoC approach to either account for the crisis or the similarities in the responses that national governments have made to it point to fundamental weaknesses in the analytical approach. Prime among these is the problem that the VoC does not offer an analysis of capitalism as such. The main concerns of contributors to the $\mathrm{VoC}$ literature have been to examine the various roles that markets, hierarchies and networks play in coordinating economic activity and to analyse the comparative advantages conferred by different institutional constellations. However, the concept of capital is not employed. There are no 'capitalists' in the VoC account, only 'firms'. By extension, Hall and Soskice, and those following in their wake, pay scant attention to the processes through which capital is accumulated and fail to distinguish between different fractions of capital. The VoC approach has focused implicitly on the manufacturing sector (Blyth, 2003; Bosch et al., 2007). Attention has been given to the role of institutions in supporting distinct corporate strategies, with an implicit focus on different types of productive activity. As far as financial capital is concerned, the focus has been on corporate governance and firms' access to finance. The close ties between banks and industry that are said to typify corporate governance in CMEs such as Germany are compared with arms-length arrangements to be found in LMEs such as the UK. In this regard, the VoC analysis contains echoes of Hilferding's concern with the fusion of banking and industrial interests and follows Gershenkron (1962) in conceptualising finance as performing an intermediary function between households and firms at a national level (Engelen and Konings, 2010: 604). The internationalisation of finance has been discussed mainly in relation to its 
potential implications for corporate governance in CMEs (Hall and Soskice, 2001: 60-62). The VoC has paid little attention to the development of finance as a distinctive fraction of capital, the ways in which representatives of finance have sought to influence government policy and the role of finance as a 'disciplining agent on capital accumulation' (Albo, 2005: 69). Financialisation has tended to be neglected because the VoC approach equates capital to the market economy, dissolving issues of exploitation, distribution and conflict into coordination mechanisms such as industrial relations institutions, training and education systems and corporate governance arrangements. Moreover, there has been a tendency to treat national economies as relatively closed, thereby underemphasising the importance of capital flows across the different VoC and the consequences for economic development. While LMEs led in the race to deregulate and enhance the power of finance capital, the connection of national financial capital systems to an evidently global financial capitalism meant that the eventual crisis and consequent contagion were experienced by all 'varieties' of capitalism (see Stiglitz, 2003).

A second problem relates to VoC's treatment of capital-labour relations. According to Hall and Soskice (2001: 24-25), many firms in CMEs rely on a highly skilled workforce and this necessitates the development of industrial relations institutions that will discourage poaching of skilled workers by firms and encourage workers to cooperate with managers. The creation of industrial relations institutions is thus explained in functionalist terms as a response to perceived risks in respect of the supply of skills. Furthermore, Hall and Soskice (2001) argued that different 'varieties of capitalism' are associated with distinct types of welfare state and training systems, and that these differences reflect and support the strategies of firms in 'coordinated' and 'liberal' market economies. Liberal social policies encourage the flexible labour markets and general skills that firms in LMEs, such as the UK and the United States, are said to demand. By contrast, stronger employment protections and superior unemployment benefits are said to encourage investments in higher level industryspecific skills that firms in CMEs, such as Austria and Germany, are said to require (Hall and Soskice, 2001: 50-51). Hall and Soskice argued that because both employers and workers in CMEs derive advantages from strong institutions, including employment and social protections, they are likely to take a common position in defence of them. Rights and entitlements in respect of welfare provision and employment are therefore likely to be maintained in CMEs. This prediction is not well supported by the evidence. Table 1 provides information about a number of measures that capture information about the strength of trade unions and worker entitlements. Taken together, they suggest that a weakening in the position of labour and an erosion of employment and social protections have been occurring in both LMEs and CMEs, albeit to varying extents.

Trade union density varies considerably, both between countries associated with different varieties of capitalism and between countries associated with the same variety. Nevertheless, density rates have declined in almost all countries, regardless of the variety of capitalism with which they are associated. Among LMEs, where collective bargaining is often enterprise-based, union membership losses have coincided with a reduction in the proportion of workers who are covered by collective bargaining. Falling density has also coincided with reduced coverage in Germany, although in most other CMEs and MMEs, coverage has been maintained and typically remains far more extensive than in LMEs. In general, inequality in countries with extensive collective bargaining coverage continues to be less pronounced than in 


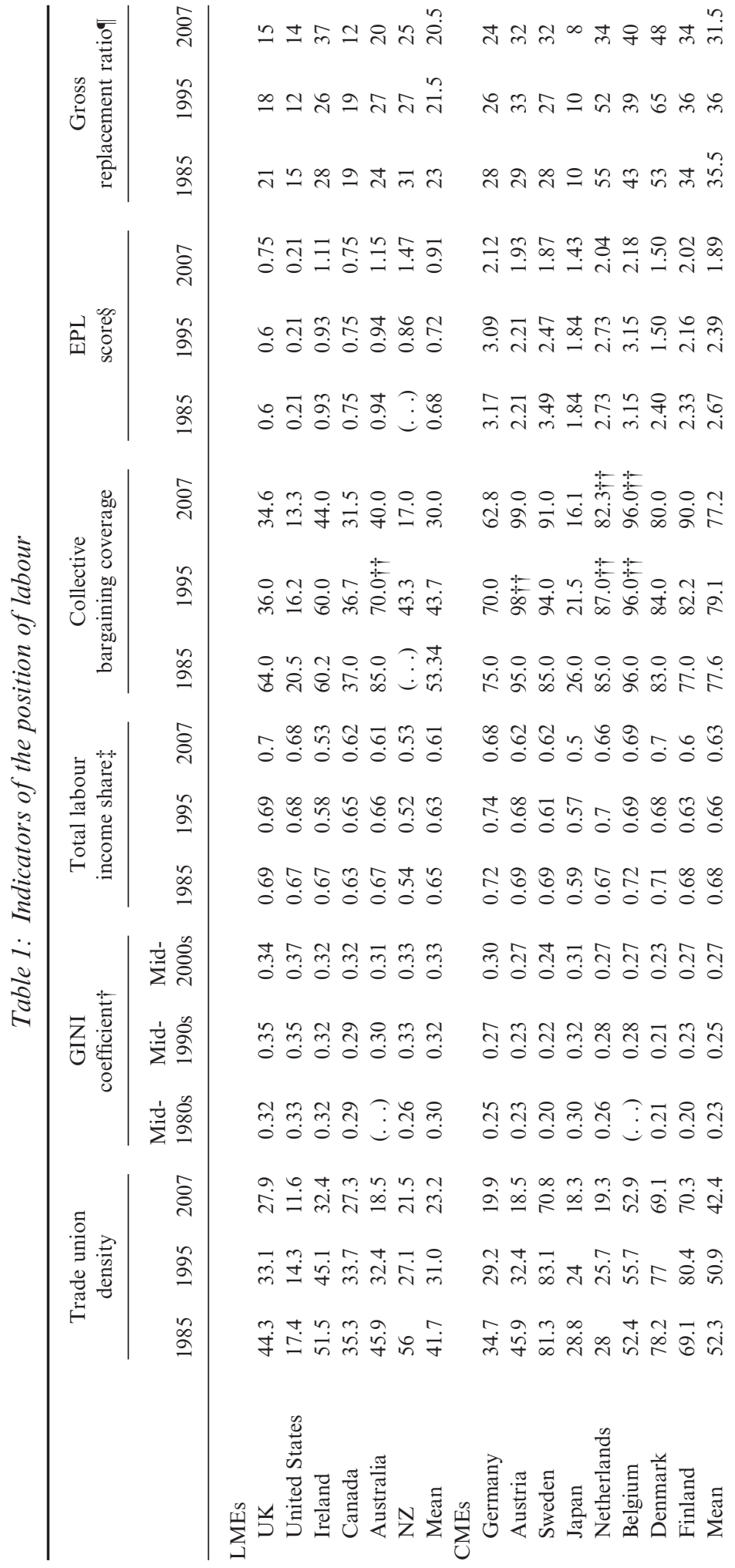




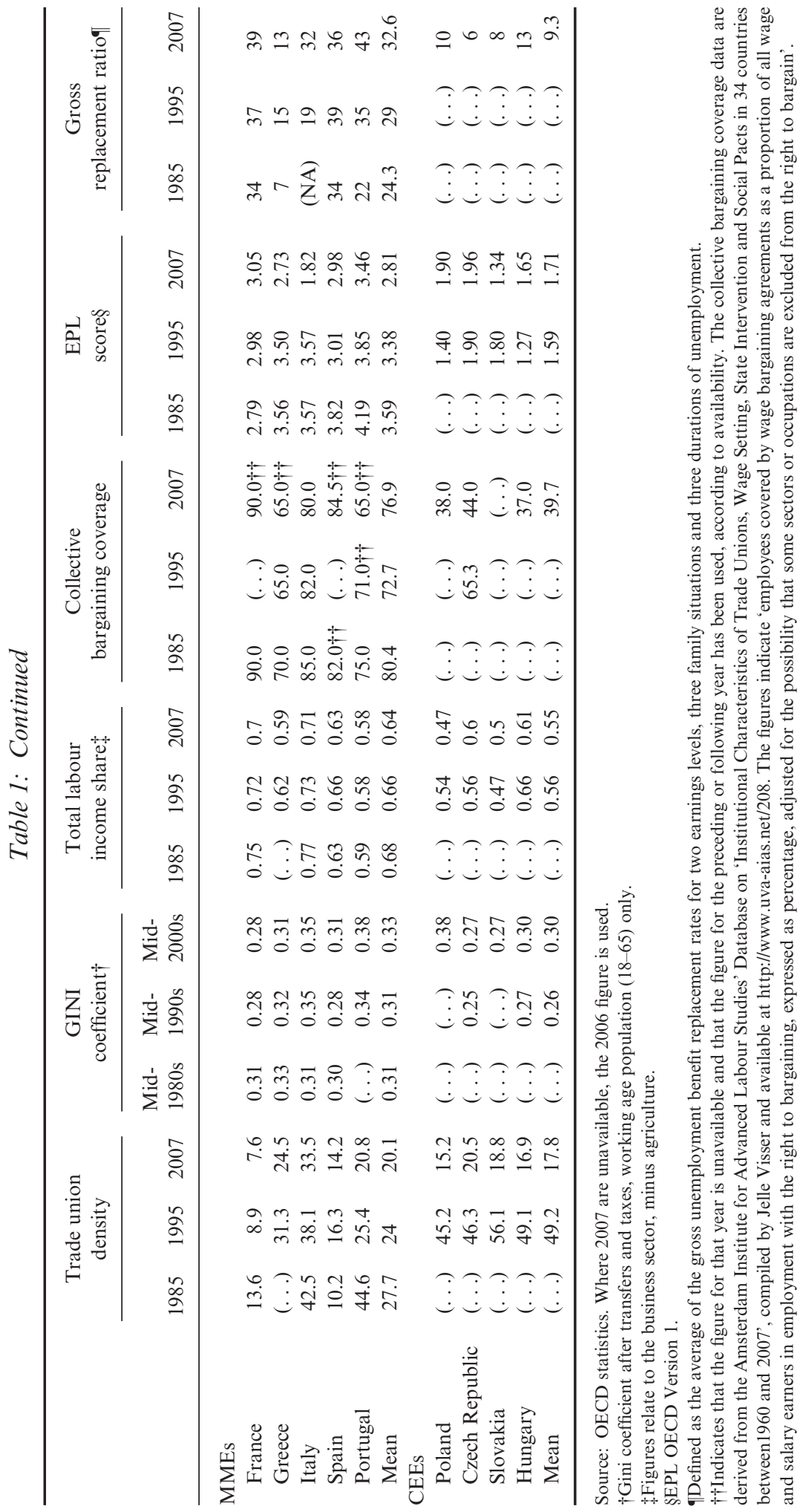


countries with more restricted coverage. However, the degree of inequality in many MMEs - as measured by the Gini coefficient - is comparable with that found among LMEs, despite marked differences in collective bargaining coverage. Moreover, the data for a number of CMEs and MMEs, including Finland, Sweden, Austria and Italy, suggest that high (and in some cases increased) levels of bargaining coverage have not necessarily prevented increases in inequality among wage earners and lower labour income shares. Apparent institutional stability may therefore mask a weakening in the ability of labour to influence distributional outcomes in these countries, particularly given the increasing emphasis that is being placed on company-level pay setting processes in most CMEs.

Labour income shares have tended to decrease in both LMEs and CMEs. The total labour income share in most of the countries listed in Table 1 was lower in 2007 than in 1985. The exceptions included the UK and the United States; however, both countries were in the vanguard of neoliberalism and experienced a downward shift in labour income share at an earlier point (the late 1970s in the case of the United States and the early 1980s in the case of the UK). New Zealand and Australia also experienced a downward trend shift in the early 1980s, as did the Netherlands. While the data for Denmark suggest stability, the labour income share from the mid-1990s onwards was consistently lower than it had been during the preceding 20 years.

The strength of employment protections, as measured by the OECD's Employment Protection Legislation index, has weakened in many countries over the past 30 years (Heyes, 2011). This is not to say that there has been an untrammelled race to the bottom: employment rights have been strengthened for some groups within some countries (for a discussion of Italy, see Michelotti and Nyland, 2008), while in some LMEs, there has been a general improvement in recent years, albeit from a very low base. The influence of European social policy has clearly exerted an important influence on employment rights in some of those countries with relatively weak protections and new member states, whose labour codes are often closely based on EU social policy (as one element of the Acquis Communitaire). European integration has also had other important implications for social protections. In various ways, social policy has been oriented towards the creation of conditions that are perceived by European policy makers as essential to maximising the competitiveness of the EU (Bosch et al., 2007; Jessop, 2002). During the early 1990s, the Maastricht convergence criteria of low inflation and reduced public deficits encouraged the view that 'social protection [is] a financial burden which blunts the competitiveness of enterprises and fuels the potential deficit' (Bouget, 2003: 679). This view was subsequently reinforced by the constraints imposed by the growth and stability pact (Annesley, 2003: 152). Furthermore, the European Commission, through the European Employment Strategy, and the OECD have encouraged a shift towards workfare-oriented social policies involving reductions in the duration of social benefits, increased restrictions on benefit entitlements and steps to link entitlements to participation in the labour market (Van Berkel, 2009). Simultaneously, the involvement of trade unions (and employers) in the management of public employment services and other institutions of labour administration has been reduced in a number of countries (Weishaupt, 2011). Again, the process has been uneven and social protections within CMEs typically remain superior to those in LMEs. A tendency towards a weakening of social protection is nevertheless apparent across both 'varieties of capitalism'.

The common tendencies in evidence in both CMEs and LMEs suggest that the influence of neoliberalism has not been confined to the latter. This is not to argue that 
economies are converging on a single model of neoliberalism. 'Domestic sources of differences' in labour policy (Hamann and Kelly, 2003), including the organisations and influence of employers and trade unions and party politics, continue to exert a strong influence on national policy mixes. National and supranational institutions and social forces have promoted and contested neoliberalism and shaped the pace and content of reforms. As Macartney (2011: 21) has recently put it, "neo-liberalisation is therefore played out differently on each national scale yet embedded within local, regional and global neoliberal impulsions and tendencies'. The consequence has been what Macartney refers to as 'variegated neo-liberalism'.

\section{CONCLUSIONS}

The seriousness of the economic crisis, its perceived roots in under-regulated market forces, and the scale of state intervention during its initial stages encouraged some journalists and other policy commentators to declare the demise of neoliberalism. However, as time has passed, it has become clear that a substantial reorientation of policy has not occurred. The opportunity to rein in the agents of finance capital was not taken and the position of labour has been further weakened as national governments have sought to re-establish fertile conditions for accumulation by slashing public spending, diluting employment and social protections, strengthening the workfare orientation of employment policies, attacking pensions and cutting public sector wages and jobs. These measures represent a continuation and intensification of neoliberal tendencies that were already apparent before the economic crisis erupted. They are also resulting in a partial reshaping of national employment regimes (Heyes A, forthcoming). This is not to say that the efforts of national governments to impose austerity measures will be met entirely with successes. Industrial action and other kinds of protest have been widespread and policy makers in some countries have been encouraged to reconsider the scale and content of austerity measures (e.g. the decision of the recently formed coalition government in Ireland to restore the value of the national minimum wage). Nevertheless, it would seem that the rumours of neoliberalism's death were premature.

While the specific content of policies differs between countries, attempts at reducing workers' rights are currently being made across all VoC. Contributors to the VoC literature (for example Iversen, 2007) have insisted that responses to 'exogenous shocks' will differ between varieties of capitalism, yet there is a clear need for analyses that are able to account for similiarities as well as differences. Moreover, the causes of the crisis should not be regarded as 'exogenous'; they are a product of processes that have been central to neoliberalism and which have been overlooked in VoCrooted comparative institutional analysis. In focusing on institutional complementarities as sources of competitive advantage, the $\mathrm{VoC}$ approach has paid insufficient attention to the processes through which capital-labour relations are being reshaped. In particular, it has neglected the role of the state in facilitating the expansion of finance and in weakening the position of labour and has also failed to incorporate the contrasting growth models that were pursued from the 1980s within the scope of its analysis. This is not to deny that studies conducted by researchers in the VoC tradition have produced valuable insights: a considerable amount has been learned about the role that institutions play in shaping economic activities and outcomes. However, $\mathrm{VoC}$ is conceptually and theoretically under-equipped to grasp the dynamics of change within and across economies. 
Recent contributions to the literature have attempted to provide VoC analysis with some dynamic content. Hancké et al. (2007), for example, had called for a more sophisticated understanding of interests in capitalist societies and greater recognition of the importance of the role of the state, which has typically received only a cursory examination in the $\mathrm{VoC}$ literature. Efforts to address these lacunae are to be welcomed. Nevertheless, despite attempts to overcome the static functionalism and equilibrium theorising associated with Hall's and Soskice's seminal work (e.g. Streeck and Thelen, 2005; 2009), the most influential approaches to theorising change within a VoC framework have maintained an emphasis on the 'complementarity' of institutions and varietal stability (Hall and Thelen, 2009: 255). Furthermore, the VoC approach also continues to struggle with the incorporation of empirical complexity. Hall and Soskice's initial distinction between LMEs and CMEs has come to be seen as too simplistic, leading scholars to propose an ever-growing number of 'mixed types' or 'hybrids' (e.g. Deeg and Jackson, 2007; Perraton and Clift, 2004). However, this suggests a creeping tendency towards having as many varieties as cases, thereby calling into question the analytical value of the ideal types associated with VoC. ${ }^{5}$ Moreover, simply adding extra varieties, such as 'regional varieties' (e.g. Amable, 2003), without a theoretical rationale for their existence invites the charge of analytical ad-hockery.

Ultimately, the analytical limitations of the $\mathrm{VoC}$, including the ongoing preoccupation with institutions and issues of coordination to be found in the post-Hall and Soskice literature, reflect a fundamental problem: VoC lacks a theory of capitalism. The crisis has made clear the need to address this deficiency. In place of VoC's focus on firms, transactions and the institutions through which they occur, there is a need to reassert the analytical primacy of the concept of capital, the various forms adopted by capital (e.g. industrial capital, interest-bearing capital) and the process of generating, realising and investing surplus value. In other words, it is important that concrete relationships between actors within particular capitalist societies be understood with reference to underlying social relations that are common to capitalist societies, the processes through which economic and social relations are reproduced and the forces that may disrupt their reproduction. As noted, it is also important that analysis pays heed to the bases upon which accumulation takes place. The state plays a critical role in moulding the characteristics of national accumulation pathways (cf. Coates, 1999) and has given concrete form to neoliberalism through policies directed at weakening labour and promoting finance capital. However, in creating the conditions in which finance might thrive - deregulating capital markets and weakening labour vis-à-vis capital - the state helped to create conditions that gave rise to the current crisis. Attempts by the state to overcome the barriers to accumulation of the 1970s therefore ultimately served to encourage the emergence of new barriers to accumulation, which governments and supranational agencies are now struggling to address. The contradictions associated with state interventions have been neglected in the VoC literature, which has tended to treat the state's role in economic and social reproduction as largely unproblematic, in that the state is generally depicted as acting so as to reproduce and reinforce institutional sources of competitive advantage. By contrast, state theorists in the Marxist tradition (e.g. Jessop, 2008; Poulantzas, 1973; 1978) have not regarded economic and social reproduction as given but have instead sought to shed light on the

\footnotetext{
${ }^{5}$ This tendency is as much the logical consequence of the 'pure' ideal type approach advocated by Crouch (2005) and Becker (2009) as it is in the 'hybrid' literature, which they criticise for blending theory and empirical cases.
} 
conditions that are necessary for reproduction to occur while seeking to explain the state's structural relationship to capitalism as a system of class relations. Issues that are largely neglected in the VoC literature, such as the exercise of power, ideology, class (and intra-class) interests and struggles, the legitimacy of state action and the difficulty of reconciling conflicting state objectives, have been core concerns for theorists of the capitalist state. These issues may be considered particularly pertinent at a time when imposed austerity measures are being met with industrial action and other forms of protest, politicians are struggling to avoid economic collapse and democratic processes are under threat. Connecting with the insights furnished by studies of the capitalist state may serve to enhance understanding of contemporary developments while assisting in the longer term task of ensuring that comparative institutional analysis is rooted in an analysis of capitalism.

\section{Acknowledgements}

We are extremely grateful to the journal's referees, Peter Nolan and Paul Edwards for providing very constructive comments on an earlier draft of this article. We are responsible for any errors that remain.

\section{References}

Albo, G. (2005), 'Contesting the "New Capitalism" , in D. Coates (ed.), Varieties of Capitalism, Varieties of Approaches (Basingstoke, Palgrave Macmillan) pp. 63-82.

Amable, B. (2003), The Diversity of Modern Capitalism (Oxford, Oxford University Press).

Annesley, C. (2003), 'Americanised and Europeanised: UK social policy since 1997', British Journal of Politics and International Relations, 5, 2, 143-165.

Baran, P. and M. Sweezy (1966), Monopoly Capital: An Essay on the American Economic and Social Order (New York, Monthly Review Press).

Becker, U. (2009), Open Varieties of Capitalism-Continuity, Change and Performances (Basingstoke, Palgrave Macmillan).

Blyth, M. (2003), 'Same as It Never Was: Temporality and Typology in the Varieties of Capitalism', Comparative European Politics, 1, 2, 215-225.

Bosch, G., J. Rubery and S. Lehndorff (2007), 'European Employment Models under Pressure to Change', International Labour Review, 146, 3/4, 253-277.

Bouget, D. (2003), 'Convergence in the social welfare systems in Europe: From goal to reality', Social Policy \& Administration 37, 6, 674-693.

Brenner, R. (2004), 'New Boom or New Bubble: The Trajectory of the US Economy', New Left Review, 25, January-February.

Callinicos, A. (2010), Bonfire of Illusions: The Twin Crises of the Liberal World (Cambridge, Polity Press).

Clark, I. (2009), 'Owners not Managers: Disconnecting Managerial Capitalism? Understanding the Take Private Equity Business Model', Work, Employment and Society, 23, 4, 359-378.

Clark, I. (2011), 'Private Equity, Union Recognition and Value Extraction at the AA', Industrial Relations Journal, 42, 1, 36-50.

Coates, D. (1999), 'Models of Capitalism in the New World Order: The UK Case', Political Studies, 47, 4, 643-660.

Crouch, C. (2005), Capitalist Diversity and Change: Recombinant Governance and Institutional Entrepreneurs (Oxford, Oxford University Press).

Deeg, R. (2010), 'Institutional Change in Financial Systems', in G. Morgan, J. L. Campbell, C. Crouch, O. K. Pedersen and R. Whitley (eds), The Oxford Handbook of Comparative Institutional Analysis (Oxford, OUP) pp. 309-334. 
Deeg, R. and G. Jackson (2007), 'Towards a More Dynamic Theory of Capitalist Variety', Socio-Economic Review, 5, 1, 149-179.

Elliott, L. and D. Atkinson (2009), The Gods that Failed: How the Financial Elites Have Gambled Away Our Futures (London, Vintage).

Engelen, E. and M. Konings (2010), 'Financial Capitalism Resurgent: Comparative Institutionalism and the Challenges of Financialization', in G. Morgan, J. L. Campbell, C. Crouch, O. K. Pedersen and R. Whitley (eds), The Oxford Handbook of Comparative Institutional Analysis (Oxford, OUP) pp. 601-624.

ESA (1995), European System of Accounts (Brussels, European Commission, Eurostat) Retrieved 24 January 2004 from http://circa.europa.eu/irc/dsis/nfaccount/info/data/esa95/ esa95-new.htm

European Commission (2010), Employment in Europe 2010 (Luxembourg, Publications Office of the European Union).

Feinstein, C. H. (1972), National Income, Expenditure and Output of the United Kingdom 1855-1965 (Cambridge, Cambridge University Press).

Folkman, P., J. Froud, K. Williams and S. Johal (2009), 'Private Equity Levered on Capital or Levered on Labour', Journal of Industrial Relations, 51, 4, 517-529.

Foster, J. B. and F. Magdoff (2009), The Great Financial Crisis: Causes and Consequences (New York, Monthly Review Press).

Froud, J., S. Johal, A. Leaver and K. Williams (2006), Financialization and Strategy: Narrative and Numbers (London, Routledge).

Gamble, A. (2009), The Spectre at the Feast: Capitalist Crisis and the Politics of Recession (Basingstoke, Palgrave Macmillan).

Gerschenkron, A. (1962), Economic Backwardness in Historical Perspective. A book of essays, (Cambridge MA, Belknap Press of Harvard University Press).

Glyn, A. (2006), Capitalism Unleashed: Finance, Globalization and Welfare (Oxford, OUP).

Haldane, A., S. Brennan and V. Madouros (2010), 'The Contribution of the Financial Sector Miracle or Mirage?', Paper given at the Future of Finance Conference, London, 14 July. Retrieved 24 January 2012 from http://www.bankofengland.co.uk/publications/speeches/ 2010/speech442.pdf

Hall, P. A. and D. Soskice (2001), 'An Introduction to Varieties of Capitalism', in P. A. Hall and D. Soskice (eds), Varieties of Capitalism: The Institutional Foundations of Comparative Advantage (Oxford, OUP) pp. 1-68.

Hall, P. A. and K. Thelen (2009), 'Institutional Change in Varieties of Capitalism', in B. Hancké (ed.), Debating Varieties of Capitalism. A Reader (Oxford, Oxford University Press) pp. 251-272.

Hamann, K. and J. Kelly (2003), 'The Domestic Sources of Differences in Labour Market Policies', British Journal of Industrial Relations, 41, 4, 639-664.

Hancké, B., M. Rhodes and M. Thatcher (2007), 'Introduction: Beyond Varieties of Capitalism', in B. Hancké, M. Rhodes and M. Thatcher (eds), Beyond Varieties of Capitalism: Conflict, Contradictions and Complementarities in the European Economy (Oxford, OUP) pp. 3-38.

Harvey, D. (2005), A Brief History of Neoliberalism (Oxford, Oxford University Press).

Harvey, D. (2010), The Enigma of Capital and the Crises of Capitalism (London, Profile Books).

Heyes, J. P. and Nolan (2010), 'The State, Capital and Labour Relations in Crisis', in T. Colling and M. Terry (eds) Industrial Relations: Theory and Practice. Third Edition. (Basingstoke, Wiley Blackwell). pp. 106-124.

Heyes, J. (2011), 'Flexicurity, Employment Protection and the Jobs Crisis', Work, Employment \& Society, 25, 4, 642-657.

Heyes, J. (Forthcoming) 'Flexicurity in Crisis: European Labour Market Policies in a Time of Austerity', European Journal of Industrial Relations.

ILO (2008), World of Work Report 2008: Income Inequalities in the Age of Financial Globalization (Geneva, ILO).

ILO (2009), World of Work Report 2009: The Global Jobs Crisis and Beyond (Geneva, ILO). 
IMF (2008), Global Financial Stability Report-Financial Stress and Deleveraging (Washington, DC, Macrofinancial Implications and Policy). October.

Iversen, T. (2007), 'Economic Shocks and Varieties of Government Responses', in B. Hanké, M. Rhodes and M. Thatcher (eds), Beyond Varieties of Capitalism (Oxford, OUP) pp. 278-304.

Jensen, M. and K. Murphy (2009), CEO Pay and What to Do about It (Cambridge, MA, Harvard Business School Press).

Jessop, B. (2002), The Future of the Capitalist State (Cambridge, Polity Press).

Jessop, B. (2008), State Power (Cambridge, Polity Press).

Khatiwada, S. (2009), Stimulus Packages to Counter Global Economic Crisis: A Review (Geneva, International Institute for Labour Studies).

King, L. P. (2007), 'Central European Capitalism in Comparative Perspective', in B. Hancké, M. Rhodes and M. Thatcher (eds), Beyond Varieties of Capitalism: Conflict, Contradictions and Complementarities in the European Economy (Oxford, OUP) pp. 307-327.

Lazonick, W. and M. O'Sullivan (2000), 'Maximising Shareholder Value: A New Ideology for Corporate Governance', Economy and Society, 29, 1, 13-35.

Lewis, P. (2009), '(How) do flexible labour markets really work? The role of profitability in influencing unemployment'. Cambridge Journal of Economics, 33, 1, 51-77.

Lewis P. C. (2010), 'The Global Financial Crisis 2007-8: Origins, Nature and Consequences', in P. Bilgin and P. D. Williams (eds), Global Security in Encyclopedia of Life Support Systems (EOLSS), (Developed under the Auspices of the UNESCO, Eolss Publishers, Oxford, UK, http://www.eolss.net)

Macartney, H. (2011), Variegated Neoliberalism: EU Varieties of Capitalism and International Political Economy (London, Routledge).

Mason, P. (2009), Meltdown: The End of the Age of Greed (London, Verso).

Michelotti, M. and C. Nyland (2008), 'Varieties of Capitalism and Diversity in Labour Standards Regulation: The Case of Italy', European Journal of Industrial Relations, 14, 2 , 177-195.

Mitchell, B. R. (1988), British Historical Statistics (Cambridge, Cambridge University Press).

Nolan, P. (2011), 'Money, Markets, Meltdown: The 21st-Century Crisis of Labour', Industrial Relations Journal, 42, 1, 2-17.

Nölke, A. and J. Perry (2007), 'The Power of Transnational Private Governance: Financialisation and the IASB', Business and Politics, 9, 4, 1-25.

O'Sullivan, M. A. (2000), Contests for Corporate Control. Corporate Governance and Economic Performance in the United States and Germany (Oxford, Oxford University Press).

Perraton, J. and B. Clift (2004), 'So Where Are National Capitalisms Now?', in J. Perraton and B. Clift (eds), Where Are National Capitalisms Now? (Basingstoke, Palgrave Macmillan) pp. $195-261$.

Philippon, T. (2008), 'The Evolution of the US Financial Industry from 1860 to 2007: Theory and Evidence', seminar paper available at http://pages.stern.nyu.edu/ tphilipp/papers/ finsize.pdf

Poulantzas, N. (1973), Political Power and Social Classes (London, New Left Books).

Poulantzas, N. (1978), State, Power, Socialism (London, Verso).

Quiggin, J. (2010), Zombie Economics: How Dead Ideas Still Walk Among Us (Princeton, NJ, Princeton University Press).

Rodrigues, S. and J. Child (2010), 'Private Equity, the Minimalist Organization and the Quality of Employment Relations', Human Relations, 63, 9, 1321-1342.

Schwartz, H. M. and L. Seabrooke (2009), The Politics of Housing Booms and Busts, (Basingstoke, Palgrave Macmillan).

Stiglitz, J. E. (2003), The Roaring Nineties: A New History of the World's Most Prosperous Decade (New York, Norton).

Streeck, W. (2009), Re-Forming Capitalism : Institutional Change in the German Political Economy (Oxford, Oxford University Press). 
Streeck, W. and K. Thelen (2005), 'Introduction: Institutional Change in Advanced Political Economies', in W. Streeck and K. Thelen (eds), Beyond Continuity: Institutional Change in Advanced Political Economies (Oxford, Oxford University Press) pp. 1-39.

Streeck, W. and K. Thelen (2009), 'Institutional Change in Advanced Political Economies', in B. Hancké (ed.), Debating Varieties of Capitalism. A Reader (Oxford, Oxford University Press) pp. 95-131.

Thompson, G. (2009), 'What's in the Frame? How the Financial Crisis If Being Packaged for Public Consumption', Economy and Society, 38, 3, 520-524.

Torres, R. (2010), 'Incomplete Crisis Responses: Socio-Economic Costs and Policy Implications', International Labour Review, 149, 2, 227-237.

Turner, A. (2009), The Turner Review. A Regulatory Response to the Global Banking Crisis (London, FSA).

Van Berkel, R. (2009), 'The Provision of Income Protection and Activation Services for the Unemployed in "Active" Welfare States. An International Comparison', Journal of Social Policy, 39, 1, 17-34.

Weeks, J. (1995), Inequality Trends in Some Developed OECD countries. UN/Department of Economic and Social Affairs Working Paper No. 6. Retrieved 24 January 2012 from <https:// www.un.org/esa/desa/papers/2005/wp6_2005.pdf>.

Weishaupt, J. T. (2011), From the Manpower Revolution to the Activation Paradigm: Explaining Institutions Continuity in an Integrating Europe (Amsterdam, Amsterdam University Press). 